\title{
PEMBERDAYAAN IBU-IBU PKK DI GRIYA KATULAMPA DENGAN KETERAMPILAN MEMBUAT MINUMAN LEMON SEREH JAHE YANG KAYA AKAN ANTIOKSIDAN SERTA PEMBIASAAN HIDUP BERSIH DAN SEHAT DI MASA PANDEMI COVID-19
}

\author{
Sara Nurmala, Ike Yulia Wiendarlina, Cantika Zaddana, dan Novi Fajar Utami \\ Program Studi Farmasi Fakultas Matematika dan Ilmu Pengetahuan Alam, Universitas Pakuan \\ Jl. Pakuan PO Box 452 Bogor 16143 Jawa Barat Indonesia \\ E-mail: sara.nurmala@unpak.ac.id
}

\begin{abstract}
ABSTRAK. Penularan Covid-19 saat ini lebih dominan tinggi ke arah kluster keluarga, maka peran keluarga dalam hal ini Ibu sangat penting dalam hal mempertahankan kondisi kesehatan keluarga tetap baik dengan menjaga imunitas tubuh dan menjaga kebersihan serta kesehatan keluarga salah satunya dengan rajin mengkonsumsi asupan yang kaya akan antioksidan. Tujuan dari kegiatan pengabdian kepada masyarakat ini adalah untuk menumbuhkan kesadaran akan bahaya penularan Civid-19 yang terjadi pada keluarga dan memberikan pemberdayaan kepada ibu-ibu PKK untuk memanfaatkan bahan-bahan yang biasa digunakan untuk memasak dibuat kedalam bentuk minuman kesehatan yang mengandung Lemon, Sereh dan Jahe yang kaya akan antioksidan sehingga diharapkan seluruh anggota keluarga memiliki imunitas yang baik. Pada kegiatan ini dilakukan beberapa tahap diantaranya yang pertama pemberian penyuluhan mengenai pentingnya menjaga kesehatan dengan pembiasaan hidup bersih dan sehat, diantaranya adalah dengan memakai masker, mencuci tangan, berolahraga dan rajin mengkonsumsi antioksidan. Setelah pemberian penyuluhan dilakukan demo bagaimana cara membuat minuman kesehatan yang mengandung Lemon, Sereh dan Jahe serta dijelaskan apa saja manfaat dari ketiga bahan tersebut untuk kesehatan. Tahap yang terakhir adalah pemeriksaan dan konsultasi yang meliputi pengukuran tekanan darah, berat badan dan tinggi badan. Hasil yang didapatkan dari kegiatan ini adalah Produk minuman Lemon, Sereh dan Jahe yang disukai oleh pada peserta pengabdian dan dapat dibuat dengan mudah di rumah sehingga diharapkan anggota keluarga di rumah memiliki imunitas tubuh yang baik untuk mencegah penularan virus Covid-19 selain membiasakan diri untuk hidup bersih dan sehat. Ibu-ibu PKK Griya Katulampa lebih mengerti dan memahami bagaimana virus Covid-19 dapat menyebar dan apa saja tindakan pencegahan penyebarannya. Dari kegiatan ini dapat disimpulkan bahwa perlunya pemberdayaan masyarakat terkait pengenalan Covid-19 dan apa saja hal-hal yang perlu dilakukan untuk menghindari tertularnya virus tersebut.
\end{abstract}

Kata kunci: Pemberdayaan Ibu PKK; Minuman Antioksidan; Lemon; Sereh; Jahe; Covid-19

ABSTRACT. Covid-19 transmission is currently more dominant towards family clusters, so the role of the family in this case is very important in terms of maintaining good family health conditions by maintaining body immunity and maintaining cleanliness and family health, one of which is diligently consuming a rich intake of food. antioxidants. The purpose of this community service activity is to raise awareness of the dangers of Civid-19 transmission that occurs in families and to empower PKK mothers to utilize ingredients commonly used for cooking made into health drinks containing lemon, lemongrass and Ginger is rich in antioxidants, so it is hoped that all family members will have good immunity. In this activity, several stages were carried out including the first to provide counseling on the importance of maintaining health with clean and healthy living habits, including wearing masks, washing hands, exercising and diligently consuming antioxidants. After the counseling, a demonstration was conducted on how to make a health drink containing lemon, lemongrass and ginger and explained what are the benefits of these three ingredients for health. The last stage is examination and consultation which includes measurement of blood pressure, weight and height. The results obtained from this activity are Lemon, Lemongrass and Ginger drink products that are liked by participants and can be made easily at home so that it is hoped that family members at home will have good immunity to prevent transmission of the Covid-19 virus besides getting used to living clean and healthy. PKK mothers of Griya Katulampa has a better understanding about how the Covid-19 virus can spread and any action to prevent its spread. From this activity, it can be concluded that it is necessary for community empowerment related to the introduction of Covid-19 and what are the things that need to be done to avoid contracting the virus.

\section{Keywords: Empowerment of PKK mothers; Antioxidant Drinks; Lemon; Lemongrass; Ginger; Covid-19.}

\section{PENDAHULUAN}

Di era pandemi Covid-19 seperti yang saat ini sedang terjadi perilaku hidup bersih dan sehat menjadi sangat penting demi menghindari paparan virus Covid-19. Antioksidan sangat berperan penting saat ini karena tubuh kita memiliki sistem kekebalan tubuh yang berbeda sehingga penting untuk mempertahankan sistem imun tubuh salah satunya dengan cara mengkonsumsi antioksidan. Antioksidan merupakan senyawa kimia kemampuannya dapat menghambat reaksi oksidasi dengan mengikat radikal bebas (Winarsi, 2007).

Lemon memiliki khasiat yang sangat tinggi sebagai antioksidan. Perasan daging buah lemon memiliki aktivitas antioksidan dengan Nilai $\mathrm{IC}_{50}$ yang diperoleh berada pada rentang $50-100$ ppm yaitu sebesar 76,83 ppm sehingga aktivitas antioksidan 
dari lemon dikatakan kuat. (Puspitasari, dkk, 2019).

Serai merupakan salah satu bumbu masakan yang biasa digunakan di rumah tangga. Serai biasanya digunakan sebagai tanaman obat. Serai wangi dapat berkhasiat sebagai obat sakit kepala, batuk, nyeri lambung, diare, penghangat badan, penurun panas dan pengusir nyamuk (Fauzi, 2009). Serai telah diuji Besarnya aktivitas antioksidan dengan uji perendaman radikal DPPH pada fraksi etil asetat sebesar 68,96 ppm. (Hendrik, dkk, 2013). Penggunaan ekstrak rempah serai pada produk dark chocolate merupakan penganekaragaman produk olahan cokelat meningkatkan kandungan antioksidan dan sifat sensori. (Pratiwy, dkk, 2019).

Jahe merah merupakan rempah-rempah yang mengandung senyawa-senyawa antioksidan alami. Besarnya aktivitas antioksidan dengan metode peredaman radikal bebas DPPH dari ekstrak jahe merah yang diperoleh adalah nilai IC50 (Inhibisi Concentration), yaitu untuk ekstrak total sebesar 32,19 ppm. (Kaban, dkk, 2016). Beberapa komponen kimia jahe, seperti gingerol, shogaol dan zingerone memberi efek farmakologi dan fisiologi seperti antioksidan. (Hernani, 2010). Ekstrak rimpang jahe gajah direbus selama 6 menit didapatkan sampel olahan termal terbaik yang ditentukan oleh GCMS dan FTIR hasilnya terbukti memiliki senyawa antioksidan yaitu methyl ester, 9-octadecenoic dan nortrachelogenin. (Purnomo, dkk, 2010). Komponenkomponen bioaktif dalam jahe yang digolongkan sebagai antioksidan primer dan tokoferol dalam tubuh, kemungkinan besar akan bekerja bersamasama sebagai pertahanan pertama terhadap serangan radikal bebas. (Zakaria, dkk, 2000).

Pembiasaan Hidup Bersih dan Sehat juga tidak hanya menjadi salah satu jalan keluar dalam menghadapi Pandemik Covid-19 ini tetapi dengan rutin mengkonsumsi makanan serta minuman yang sehat diharapkan dapat meningkatkan system imun Berdasarkan latar belakang yang telah disampaikan, dimana pada era pandemi covid-19 ini kondisi mitra yang dalam hal ini ibu rumah tangga dalam suatu keluarga yang masih perlu mendapatkan pemberdayaan keterampilan untuk berinisiatif menciptakan lingkungan keluarga yang sehat dimulai dengan rajin mengkonsumsi makanan atau minuman yang kaya akan antioksidan, menjaga kesehatan dan selalu memakai masker, menjaga jarak dan mencuci tangan. (Kemensos, 2020)

Sebagai sarana Peningkatan Kesadaran Masyarakat Griya Katulampa mengenai pentingnya menjaga kesehatan yang dimulai dari diri sendiri dengan pembiasaan hidup bersih dan sehat salah satunya dengan cara memakai masker, menjaga jarak dan mencuci tangan dengan sabun secara berkala.
Perlunya pemberdayaan Masyarakat dengan memberikan keterampilan membuat minuman yang kaya akan antioksidan dengan bahan-bahan yang sangat terjangkau dan mudah ditemukan. Sehingga diharapkan menjadi kebiasaan baru dalam hal mengkonsumsi antioksidan untuk meningkatkan imunitas tubuh di era pandemi ini. Pemberdayaan dilakukankepadaibu-iburumah tanggayang berperan penting terhadap kesehatan anggota keluarganya dan diharapkan setelah kegiatan ini ibu-ibu akan lebih produktif dalam menjaga kesehatan keluarga dari makanan dan minuman yang dikonsumsi.

\section{METODE}

Kegiatan PKM ini dilaksanakan di Griya Katulampa Bogor. Metode Pelaksanaan yang kami lakukan antara lain pemberdayaan mengenai beberapa halyang bertujuan sama yaitu meningkatkan kualitas kesehatan masyarakat Babakan Madang yang dimulai dari kluster terkecil yaitu keluarga dengan metode sebagai berikut:

1. Pemberian pelatihan keterampilan cara membuat minuman kesehatan yang terjangkau dan kaya akan antioksidan sehingga diharapkan ibu-ibu dapat membuat sendiri di rumah masing-masing untuk diberikan kepada keluarga sebagai usaha untuk meningkatkan sistem imunitas di masa pandemi ini.

2. Memberikan Penyuluhan tentang pembiasaan hidup bersih dan sehat yang perlu dimulai dari diri sendiri dalam hal menjaga kesehatan dan diri dari paparan virus atau bakteri di masa Pandemi saat ini. Pembiasaan tersebut antara lain memakai masker saat berada di luar rumah, menjaga jarak minimal 2 meter saat berbicara dengan orang lain dan pembiasaan dalam hal mencuci tangan. Kegiatan Penyuluhan ini diberikan pada ibuibu PKK di Griya Katulampa. Dengan adanya kegiatan ini kami berharap meningkatnya kesadaran masyarakat yang mengikuti kegiatan ini untuk kemudian diaplikasikan dalam keluarga dan kerabat dalam hal menjaga kesehatan dan kebersihan diri di masa pandemi ini

3. Melakukan Konsultasi Kesehatan Gratis dengan para Farmasis mengenai cara meningkatkan sistem imunitas agar tetap sehat di masa Pandemik serta pemeriksaan kesehatan seperti cek tekanan darah, berat badan dan tinggi badan.

Setelah Peserta dipastikan dalam keadaan sehat, Peserta yang telah mengisi daftar hadir dapat memasuki ruang kegiatan dengan tetap memakai Masker. Peserta mendapatkan Penyuluhan mengenai Pembiasaan Hidup Bersih dan Sehat di masa Pandemi Covid-19, diharapkan kesadaran akan 
melakukan pembiasaan hidup bersih dan sehat dapat terus dilakukan khususnya pada keluarga di rumah dan untuk masyarakat sekitar umumnya. Setelah selesai diberikan penyuluhan Peserta diperlihatkan Demo membuat minuman herbal yang mengandung Lemon, sereh dan jahe yang mengandung antioksidan yang sangat tinggi. Diakhir kegiatan Peserta dapat melakukan konsultasi kesehatan terkait Tekanan Darah, Gizi, Berat Badan dan Tinggi Badan.

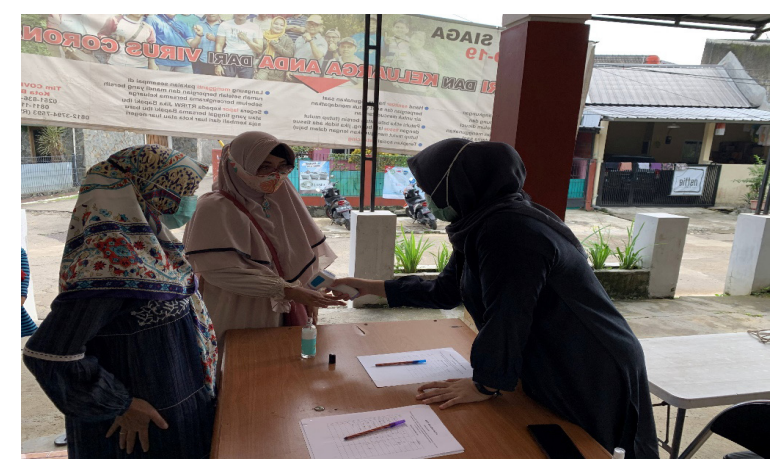

Gambar 1. Pemeriksaan Suhu Tubuh

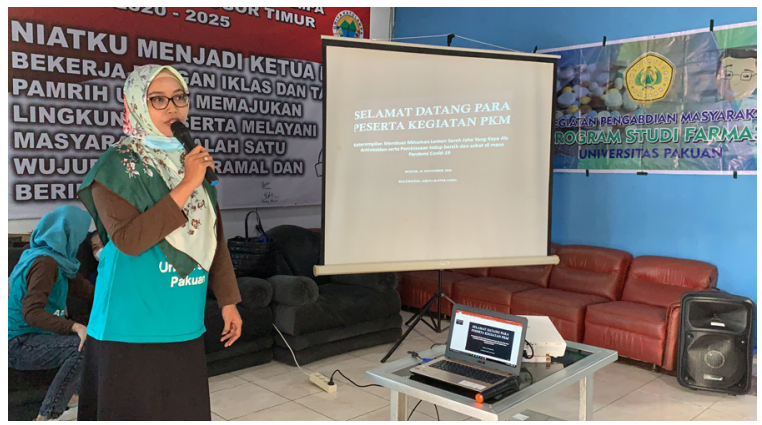

Gambar 2. Penyambutan Peserta Kegiatan

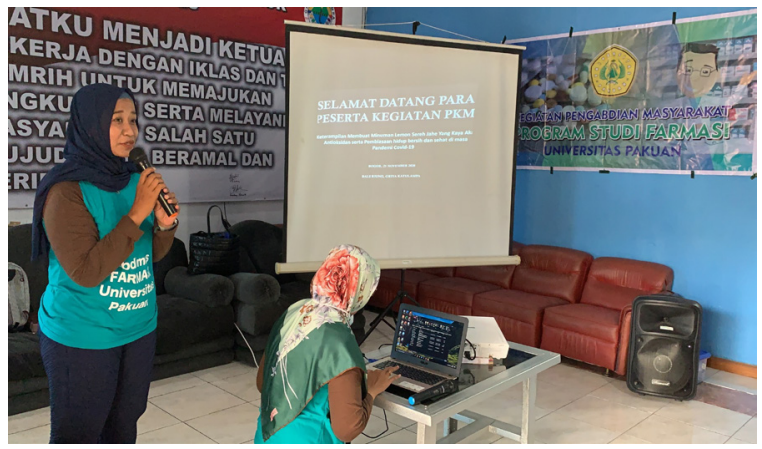

Gambar 3. Penyuluhan PHBS

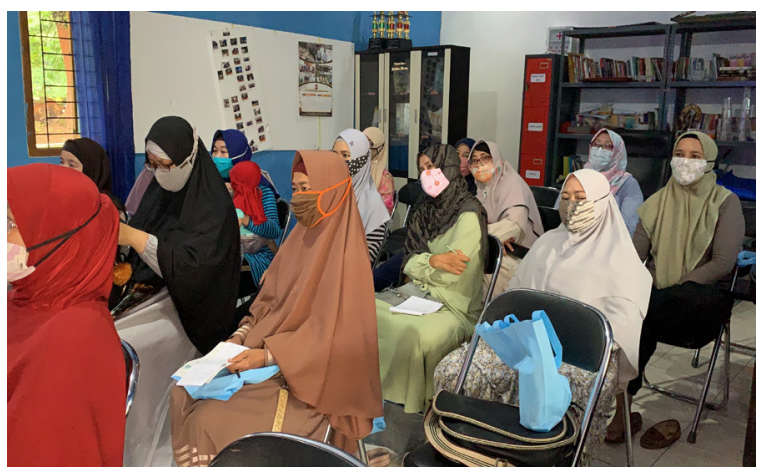

Gambar 4. Peserta Kegiatan tetap menjaga Protokol Kesehatan Saat Kegiatan

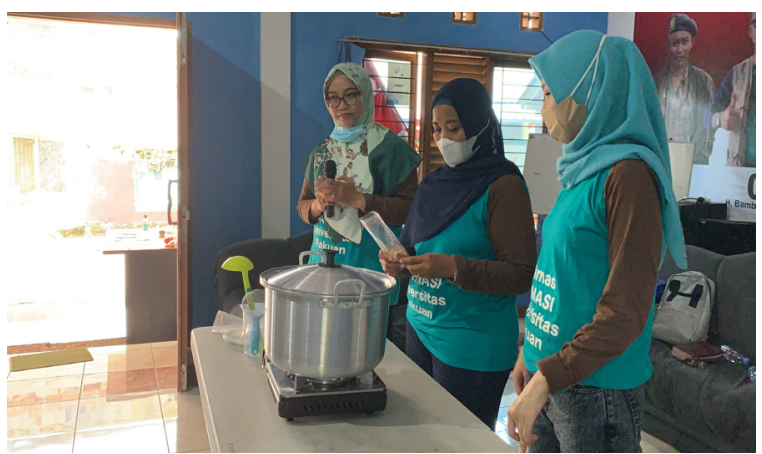

Gambar 5. DEMO Pembuatan Minuman Herbal

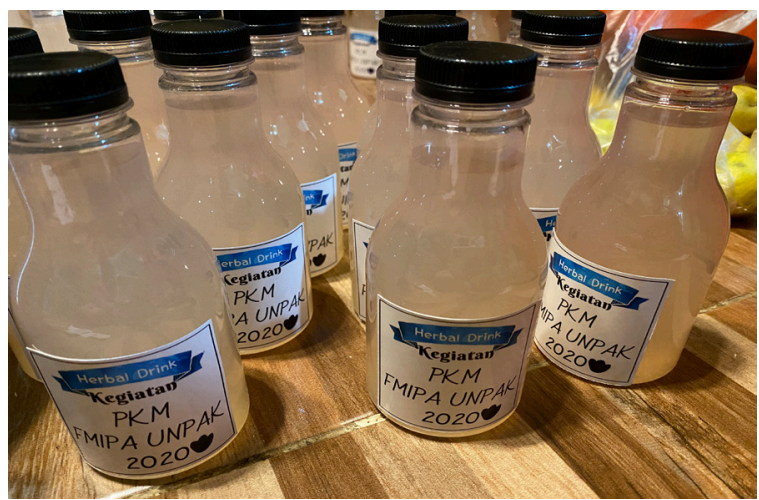

Gambar 6. Produk Minuman Herbal

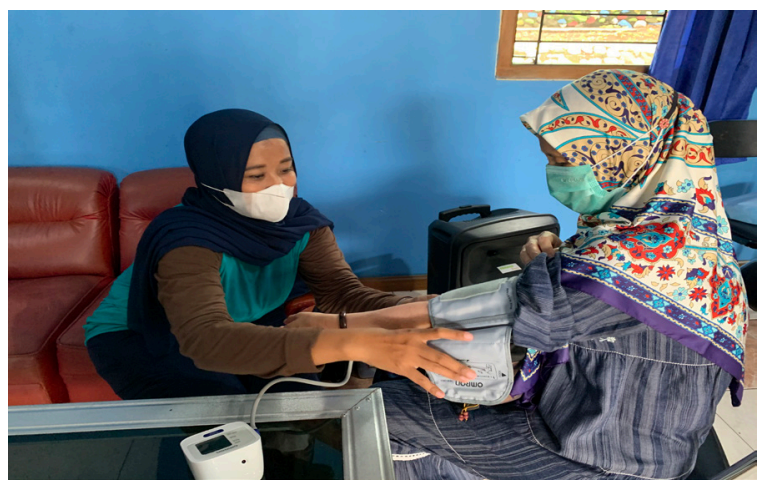

Gambar 7. Pengecekan Tekanan Darah

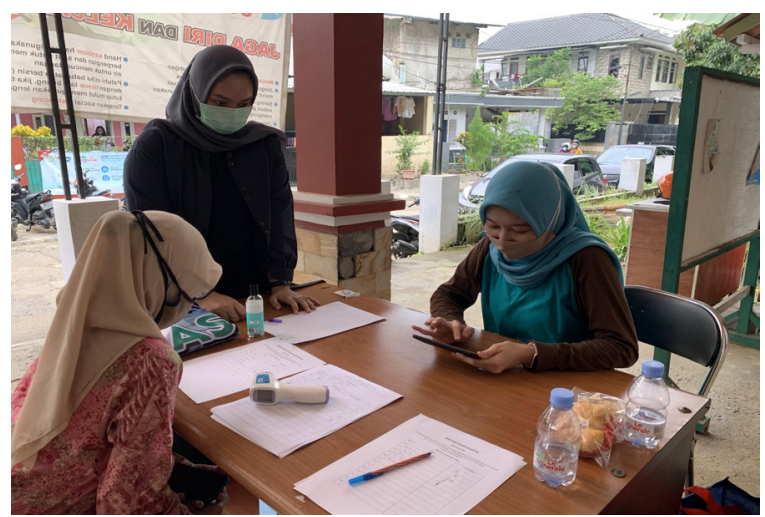

Gambar 8. Konsultasi Gizi

\section{HASIL DAN PEMBAHASAN}

Kegiatan Pengabdian Kepada Masyarakat yang berjudul Pemberdayaan Ibu-Ibu PKK di Griya Katulampa dengan Keterampilan Membuat Minuman Lemon Sereh Jahe Yang Kaya Akan Antioksidan serta Pembiasaan hidup bersih dan sehat 
di masa Pandemi Covid-19 di Griya Katulampa diikuti oleh 19 Peserta.

Penyuluhan Pembiasaaan Hidup Bersih dan Sehat telah tersampaikan kepada warga masyarakat Griya Katulampa dengan sangat baik dan diterima dengan sangat baik.

Peserta telah diberikan pelayanan kesehatan yang meliputi konsultasi kesehatan, pemeriksaan tekanan darah, Berat Badan dan Tinggi Badan. Meningkatnya pengetahuan Masyarakat mengenai caramemanfaatkan bahan alam yang biasa digunakan di rumah untuk dibuat minuman kesehatan yang kaya akan antioksidan.

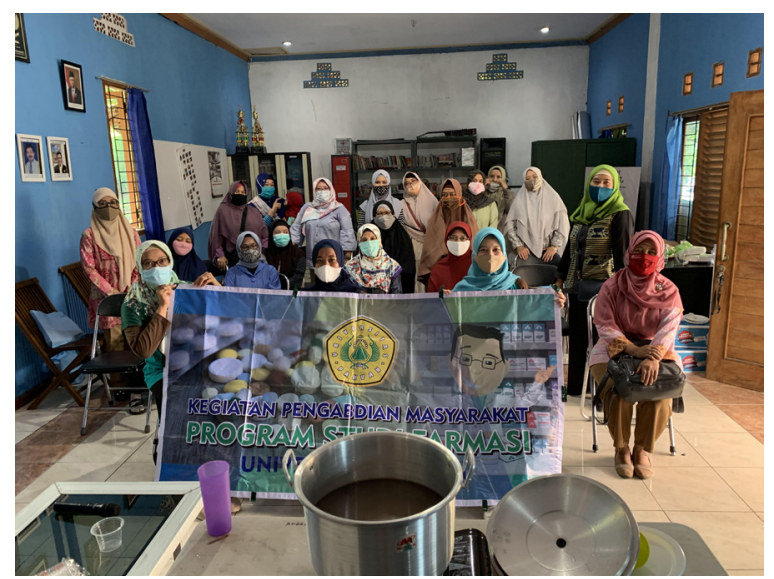

Gambar 9. Foto Bersama Peserta PKM

\section{SIMPULAN}

Dari kegiatan pemberdayaan ini Ibu-Ibu PKK Griya Katulampa mendapatkan keterampilan dalam membuat minuman kesehatan yang mengandung Lemon, Sereh dan Jahe yang kaya akan antioksidan serta menyadari pentingnya pembiasaan hidup bersih dan sehat didalam keluarga pada masa pandemi Covid-19 untuk mengurangi penularan.

\section{UCAPAN TERIMA KASIH}

Kami sampaikan ucapan terima kasih kepada Dekan Fakultas Matematika dan Ilmu Pengetahuan Alam Universitas Pakuan yang telah mendanai kegiatan PKM kami ini sehingga Masyarakat khususnya di Griya Katulampa mendapatkan pengetahuan dan keterampilan yang baru setelah mengikuti kegiatan PKM ini.

\section{DAFTAR PUSTAKA}

Winarsi, H. 2007. Antioksidan Alami \& Radikal Bebas. Yogyakarta : Penerbit Kanisius.

Puspitasari, A, D,. Susanti, E,. Khustiana, A,. 2019. Aktivitas Antioksidan Dan Penetapan Kadar Vitamin C Perasan Daging Buah Lemon (Citrus limon (L.) Osbeck) Menggunakan Metode ABTS. Jurnal Ilmiah Teknosains, 5(2).

Fauzi, A. 2009. Aneka Tanaman Obat dan Khasiatnya. Yogyakarta : Penerbit Media Pressindo

Hendrik, W,G., Erwin., Panggabean, A, S. 2013. Pemanfaatan Tumbuhan Serai Wangi (Cymbopogon Nardus (L.) Rendle) Sebagai Antioksidan Alami. Jurnal Kimia Mulawarman. 10(2) : 74-79.

Pratiwy, A, E., Kusumaningrum, I., Aminullah. 2019. Pemanfaatan Ekstrak Rempah Serai Cymbopogon Citratus Terhadap Kandungan Antioksidan Dan Sifat Sensori Produk Dark Chocolate. Jurnal Pertanian. 10 (2) : 80-92.

Kaban, A, N,. Daniel,. Saleh, C,. 2016. Uji Fitokimia, Toksisitas Dan Aktivitas Antioksidan Fraksi N-Heksan dan Etil Asetat Terhadap Ekstrak Jahe Merah (Zingiber officinale var. amarum.). Jurnal Kimia Mulawarman. 14(1).

Hernani dan Christina, W. 2010. Kandungan bahan aktif jahe dan pemanfaatannya dalam bidang kesehatan. Balai Besar Pascapanen. Bogor.

Purnomo, H., Jaya, F. dan Widjanarko, S.B. 2010. The Effects of Type and Time of Thermal Processing on Ginger (Zingiber offinacinale Roscoe) Rhizome Antioxidant Coumpounds and Its Quality. International Food Research Journal. Brawijaya University, Malang.

Zakaria, F, R,. Susanto, H,. Hartoyo, A,. 2000. Pengaruh Konsumsi Jahe (Zingiber officinale Roscoe) Terhadap Kadar Malonaldehida dan Vitamin E Plasma Pada Mahasiswa Pesantren Ulil Albaab Kedung Badak, Bogor. Buletin Teknologi dan Industri Pangan. 11(1)

Kementerian Sosial Republik Indonesia. 2020. Perilaku Hidup Bersih dan Sehat (PHBS) 